University of Nebraska - Lincoln

DigitalCommons@University of Nebraska - Lincoln

\title{
Abundance of Plodia interpunctella (Hubner) and Cadra cautella (Walker) infesting maize stored on South Carolina farms: seasonal and non-seasonal variation
}

Richard T. Arbogast

USDA-ARS

Shahpar R. Chini

USDA-ARS

Follow this and additional works at: https://digitalcommons.unl.edu/usdaarsfacpub

Part of the Agricultural Science Commons

Arbogast, Richard T. and Chini, Shahpar R., "Abundance of Plodia interpunctella (Hubner) and Cadra cautella (Walker) infesting maize stored on South Carolina farms: seasonal and non-seasonal variation" (2005). Publications from USDA-ARS / UNL Faculty. 326.

https://digitalcommons.unl.edu/usdaarsfacpub/326

This Article is brought to you for free and open access by the U.S. Department of Agriculture: Agricultural Research Service, Lincoln, Nebraska at DigitalCommons@University of Nebraska - Lincoln. It has been accepted for inclusion in Publications from USDA-ARS / UNL Faculty by an authorized administrator of DigitalCommons@University of Nebraska - Lincoln. 


\title{
Abundance of Plodia interpunctella (Hübner) and Cadra cautella (Walker) infesting maize stored on South Carolina farms: seasonal and non-seasonal variation ts
}

\author{
Richard T. Arbogast*, Shahpar R. Chini \\ Center for Medical, Agricultural and Veterinary Entomology, ARS, USDA, P.O. Box 14565, Gainesville, FL 32604, USA
}

Accepted 1 October 2004

\begin{abstract}
Seasonal trends and short-term fluctuations in abundance of Plodia interpunctella (Hübner) and Cadra cautella (Walker) infesting maize stored on two South Carolina farms were studied during three storage seasons (September 1990-June 1993). Coils of corrugated paper placed on the grain surface were used to trap mature larvae seeking pupation sites. Temperatures in the grain (18-cm-deep) and in the bin headspace were recorded hourly, and grain moisture content was measured weekly. Weekly mean numbers of moth larvae, and adults of two natural enemies, trapped in the coils were used for tracking changes in their abundance over time. The most significant findings were: (1) a seasonal pattern of abundance in both moth species that persisted from farm to farm and year to year, and (2) the coincidence of the highest population levels with the lowest temperatures. With few exceptions, the moth populations increased in the fall, reached their highest levels in winter, and then declined to low levels by early spring. The persistence of this pattern suggests a seasonal regulatory mechanism, with onset of low temperature as the primary initiator of population decline and adversely high temperature as a contributor to its protraction through spring into early summer. This view is supported by our observations of temperature and moth abundance, in conjunction with published information on the biological limitations of the two species. However, other factors, such as predators, parasitoids, and viral infection, may have contributed to the final population

\footnotetext{
The use of trade, firm, or corporation names in this publication is for the information and convenience of the reader. Such use does not constitute an official endorsement or approval by the United States Department of Agriculture or the Agricultural Research Service of any product or service to the exclusion of others that may be suitable.

${ }^{*}$ Corresponding author. Fax: + 13523745707.

E-mail address: tarbogast@gainesville.usda.ufl.edu (R.T. Arbogast).
} 
collapse. Superimposed upon the seasonal trends were short-term, non-seasonal cycles of abundance with variable periods. Population theory suggests that predation, parasitism, disease, and competition may have produced these cycles.

Published by Elsevier Ltd.

Keywords: Trapping; Population cycles; Plodia interpunctella; Cadra cautella; Stored-product insects

\section{Introduction}

Plodia interpunctella (Hübner) and Cadra cautella (Walker) (Lepidoptera: Pyralidae) are cosmopolitan species known to infest a wide range of dried plant materials, including grain and cereal products (Cox and Bell, 1991). Both species occur frequently in farm-stored maize in South Carolina, but Plodia occurs more frequently than Cadra and is usually more abundant (Arbogast and Throne, 1997).

Plodia interpunctella, C. cautella, and various other species of stored-product pyralids have frequently been studied in the laboratory and occasionally in warehouses or other commercial settings (Cox and Bell, 1991). Both approaches are important to understanding their population dynamics and developing integrated strategies for managing infestations in commercial facilities. Benson (1973) reviewed the biology of $P$. interpunctella and $C$. cautella and examined various mortality factors that may be of importance in their population dynamics. Warehouse studies have examined population trends of pyralid moths infesting bulk grain (Richards and Waloff, 1946), bagged maize (Graham, 1970), citrus pulp (Hagstrum and Sharp, 1975), and groundnuts (Keever et al., 1985), but the dynamics of populations in storage environments remain poorly understood.

The nature of the grain storage habitat on South Carolina farms and the diversity of insect populations that occur there were described by Horton (1982) and by Arbogast and Throne (1997). The present paper reports an extension of these studies, which examined temporal variation in abundance of $P$. interpunctella and $C$. cautella infesting stored maize. The principle objective was to identify seasonal trends in the moth populations and to seek underlying mechanisms, with emphasis on temperature and grain moisture content. However, short-term variation in abundance was also given consideration, and any factor that could affect population growth was at least noted.

\section{Materials and methods}

\subsection{The storage situation}

The data examined in the present study are from observations of shelled maize stored in galvanized steel bins on two South Carolina farms; the observations spanned three storage seasons or nearly 3 years, September 1990-June 1993. The two farms were located about $35 \mathrm{~km}$ apart, one in Bamberg County and the other in Barnwell County. On the Bamberg farm, the same bin, which was $5.5 \mathrm{~m}$ in diameter by $5.5 \mathrm{~m}$ high (capacity of about $85 \mathrm{t}$ ), was used for all three 
storage seasons. Three different bins, all of which were $7.3 \mathrm{~m}$ in diameter by $6.1 \mathrm{~m}$ high (capacity of about $175 \mathrm{t}$ ), were used on the Barnwell farm. Those used during the first two storage seasons were adjacent to one another; the third was located at another site about $5 \mathrm{~km}$ away. With the exception of the Barnwell bin, which was filled to $84 \%$ capacity during the third storage season (1992-1993), the bins were always filled to more than $90 \%$ capacity. All of the grain was treated with malathion at about $8 \mathrm{ppm}$, either as a $1 \%$ dust or a $1 \%$ spray, as it was loaded.

\subsection{Measurement and analysis of temperature and grain moisture content}

Grain temperature and temperature in the head space of the bins were measured and recorded by means of TP10 thermistor probes and an Easy Logger Field Unit (Model FA-110, Omnidata, Logan, UT) as described by Arbogast et al. (2000). Temperature was measured every $10 \mathrm{~min}$, and hourly averages were recorded on a data storage module (Omnidata DSM 100) for later downloading to computer storage. Nine thermistor probes arranged along north-south and east-west diameters of the bins measured grain temperatures at various points near the surface of the bulk. One probe was located at the center of the bin, four at a distance of about $15 \mathrm{~cm}$ from the bin wall, and four halfway between the center and the wall (either 1.4 or $1.8 \mathrm{~m}$ from the center, depending on the diameter of the bin). Each probe was secured with a tape to a 38-cm length of $1.8-\mathrm{cm}$ dowel rod, tapered and rounded at one end. One of the rods was suspended above the center of the bin, about halfway between the bin roof and the grain surface, to measure temperature in the headspace. The remaining rods were pushed into the grain so that the sensor, which rested in a shallow groove near the tapered end, was $18 \mathrm{~cm}$ below the surface.

The raw temperature data were processed and analyzed with SAS programs (Release 8.2, SAS Institute Inc., Cary, NC). For each farm and storage period, the nine grain temperatures recorded every hour were averaged to obtain hourly means for the bin, and the nine individual records were then dropped. The resulting data sets, which contained hourly bin means and hourly headspace readings were used to calculate descriptive statistics for each farm and season (Table 1). The data sets were then combined and used to create a data set for each month (across farms and storage periods). These monthly data sets were in turn used to calculate: (1) mean, maximum, and minimum headspace and grain temperatures by month (Fig. 1A, B); (2) the frequency of various hourly temperatures (using the SAS Freq Procedure) (Fig. 2) and (3) mean maximum and mean minimum temperatures for each hour of the day by month (Fig. 3). To examine spatial distribution of grain temperature by month, the raw data files for both farms and all three storage periods were combined, and headspace temperature was dropped. The resulting data set, which consisted of hourly grain temperatures for all nine thermistor locations, was divided into two data sets representing north-south and east-west bin diameters. Mean daily maximum and minimum temperatures at each location were then calculated for each month (Fig. 4). Isothermal maps (Figs. 3, 4) were drawn with Surfer 7.0 (Golden Software, Golden, CO) software using multiquadric (radial basis function) interpolation and default values of the function parameters $R^{2}$ (smoothing) and $h$ (anisotropy).

Nine half-liter grain samples were taken at weekly intervals from the surface of the grain for measurement of moisture content. The samples were held $(24-48 \mathrm{~h})$ in sealed polypropylene jars until moisture content could be measured with a Motomco Model 919 Automatic Grain Moisture Tester (Dickey-John, Auburn, Il). During the first two storage seasons (1990-1992), one sample 
Table 1

Descriptive statistics, by location and storage season, for grain and headspace temperatures in maize storages on South Carolina farms

\begin{tabular}{|c|c|c|c|c|c|c|c|c|}
\hline \multirow[t]{2}{*}{ Locations and dates } & \multicolumn{4}{|c|}{ Grain temperature $\left({ }^{\circ} \mathrm{C}\right)$} & \multicolumn{4}{|c|}{ Headspace temperature $\left({ }^{\circ} \mathrm{C}\right)$} \\
\hline & $N^{\mathrm{a}}$ & Mean \pm SD & Min & $\operatorname{Max}$ & $N^{\mathrm{a}}$ & Mean \pm SD & Min & $\operatorname{Max}$ \\
\hline \multicolumn{9}{|l|}{ Bamberg County } \\
\hline 28 Sep 1990-25 Jun 1991 & $237^{\mathrm{b}}$ & $20.5 \pm 6.4$ & 4.1 & 33.9 & 271 & $19.5 \pm 8.4$ & -8.0 & 58.8 \\
\hline 05 Sep 1991-13 May 1992 & 252 & $16.9 \pm 5.8$ & 6.5 & 30.5 & 252 & $16.5 \pm 7.1$ & -8.1 & 54.0 \\
\hline 18 Sep 1992-15 Jun 1993 & 271 & $17.5 \pm 7.3$ & 7.0 & 28.0 & 271 & $17.3 \pm 8.2$ & -7.4 & 58.6 \\
\hline \multicolumn{9}{|l|}{ Barnwell County } \\
\hline 08 Sep 1990-28 May 1991 & 263 & $19.2 \pm 6.5$ & 8.4 & 31.0 & 263 & $18.2 \pm 7.3$ & -6.9 & 52.7 \\
\hline 26 Sep 1991-29 Apr 1992 & 217 & $16.5 \pm 4.4$ & 8.9 & 27.8 & 217 & $15.7 \pm 5.9$ & -4.8 & 50.8 \\
\hline 11 Nov 1992-17 Jun 1993 & $203^{\mathrm{c}}$ & $15.6 \pm 4.8$ & 8.9 & 31.0 & $203^{\mathrm{b}}$ & $15.5 \pm 7.7$ & -6.3 & 50.3 \\
\hline
\end{tabular}

Grain temperature statistics were calculated from hourly bin means (average of the nine temperature records for each hour). Headspace temperature statistics were calculated directly from the hourly records.

${ }^{a}$ Number of daily means used in calculating the mean for the storage period.

${ }^{\mathrm{b}}$ Thirty-four days missing due to equipment malfunction.

${ }^{\mathrm{c}}$ Sixteen days missing due to equipment malfunction.

was taken at the center of the bin and two samples from each bin quadrant (centered on the north-south and east-west bin diameters). In each quadrant, one sample was taken from near the bin wall and one about half way between the center and the wall. The locations sampled thus varied from week to week. During the third storage season (1992-1993), one sample was taken adjacent to each temperature probe, so that the same location was sampled each week. The nine moisture readings for each week were used to obtain weekly means, maxima, and minima, which were in turn used to calculate descriptive statistics for each farm and storage season (Table 2). The weekly values were also pooled and used to determine monthly means, maxima, and minima across farms and storage seasons. (Fig. 1C).

\subsection{Trapping of moth larvae and natural enemies}

Rolls (coils) of corrugated paper, $13 \mathrm{~cm}$ in diameter, were secured with tape and cut into $2.5-\mathrm{cm}$ sections which were laid on the grain surface to trap mature wandering larvae. The open corrugations are highly attractive to larvae seeking pupation sites, so the coils provide an effective method of sampling this larval stage. For the purpose of sampling, the bin was divided into four quadrants, each centered on one of the four major cardinal points of the compass, and two coils were placed at random on the grain surface in each bin quadrant. The coils were collected at weekly intervals and replaced with fresh coils. The coils with insects were placed in zip lock plastic bags and placed in a cooler for transport to the lab, where they were opened and the larvae of $P$. interpunctella and C. cautella counted. Larvae of the two species were separated using the characters given by Richards and Thomson (1932). Pupae were held at $30^{\circ} \mathrm{C}, 60 \%$ r.h., and the adults that emerged were identified and their numbers added to the appropriate larval count. The coils were also examined for predators, parasitoids, and disease; numbers of adult Xylocoris 
flavipes (Reuter) (Hemiptera: Anthocoridae) and Habrobracon hebetor (Say) (Hymenoptera: Braconidae) were recorded.

We used availability as a relative measure for tracking changes in abundance (population density) of the moths and their natural enemies. Availability, which can be defined as the ratio of total catch to total effort - trap catch/(number of traps $\times$ trapping period) - offers a direct approach to using and interpreting population data obtained by relative methods such as trapping (Southwood, 1978). The mean number of moth larvae per coil reflects the number seeking pupation sites during any given week and thus measures availability for pupation (Fig. 5). The mean number of predators or parasitoids per coil, measures their availability for attacking moth larvae. Seasonal patterns of abundance were tracked by plotting availability against time, with midweek dates as $x$-coordinates (Fig. 5). To determine seasonal trends in abundance, we normalized the values of availability (transformed them to a common scale) by converting them to relative frequency (total captured each week/total captured during the storage season). The normalized values were averaged over all years and locations and then plotted against time (weeks after September 1) (Fig. 6). Various curves were fitted to these plots using TableCurve 2D version 5.01 (Systat, Richmond, CA).

\section{Results and discussion}

\subsection{Temperature and moisture content}

Pyralid moths infesting bulk grain occur largely in the headspace of storage structures and in a shallow layer of grain at or near the surface. The temperature and moisture regimes of this zone are therefore of particular importance in the population dynamics of these moths; details of these regimes, as observed in maize storages on South Carolina farms, are described in the following paragraphs.

Temperature means, maxima and minima for storage seasons did not vary widely from farm to farm or year to year, either in the grain or in the bin headspace (Table 1). Mean headspace temperatures differed little from those of the grain at a depth of $18 \mathrm{~cm}$; storage period means (both farms and all years combined) were 19.2 and $19.4^{\circ} \mathrm{C}$ for headspace and grain temperature, respectively. In spite of their nearly identical means, the two temperature regimes differed radically with respect to diurnal and seasonal fluctuations (Fig. 1A, B). Although the extremes of headspace and grain temperature coincided in time, the average monthly range of headspace temperature was nearly twice that of grain temperature, 27.7 as opposed to $14.5^{\circ} \mathrm{C}$; the temperature extremes were -8.1 and $58.8^{\circ} \mathrm{C}$ in the headspace, 4.1 and $36.4^{\circ} \mathrm{C}$ in the grain (Fig. $1 \mathrm{~A}, \mathrm{~B})$. Temperatures $\leqslant 0^{\circ} \mathrm{C}$ occurred in the headspace as early as November and as late as April (Fig. 1A), but grain temperature never fell below freezing (Fig. 1B). The frequency of hours with temperature extremes beyond certain biological limits of the moths are presented in Fig. 2.

Isothermal analysis of headspace temperatures showed a wide range of diurnal, as well as seasonal variation (Fig. 3A, B). The highest maxima (Fig. 3A) and minima (Fig. 3B), which were centered around 1400 (Standard Time), became progressively lower from September to January and then higher from January to June. At night, during early fall and late spring, headspace maxima ranged from 20 to 25 and minima from 15 to $20^{\circ} \mathrm{C}$. From late fall to early spring, 

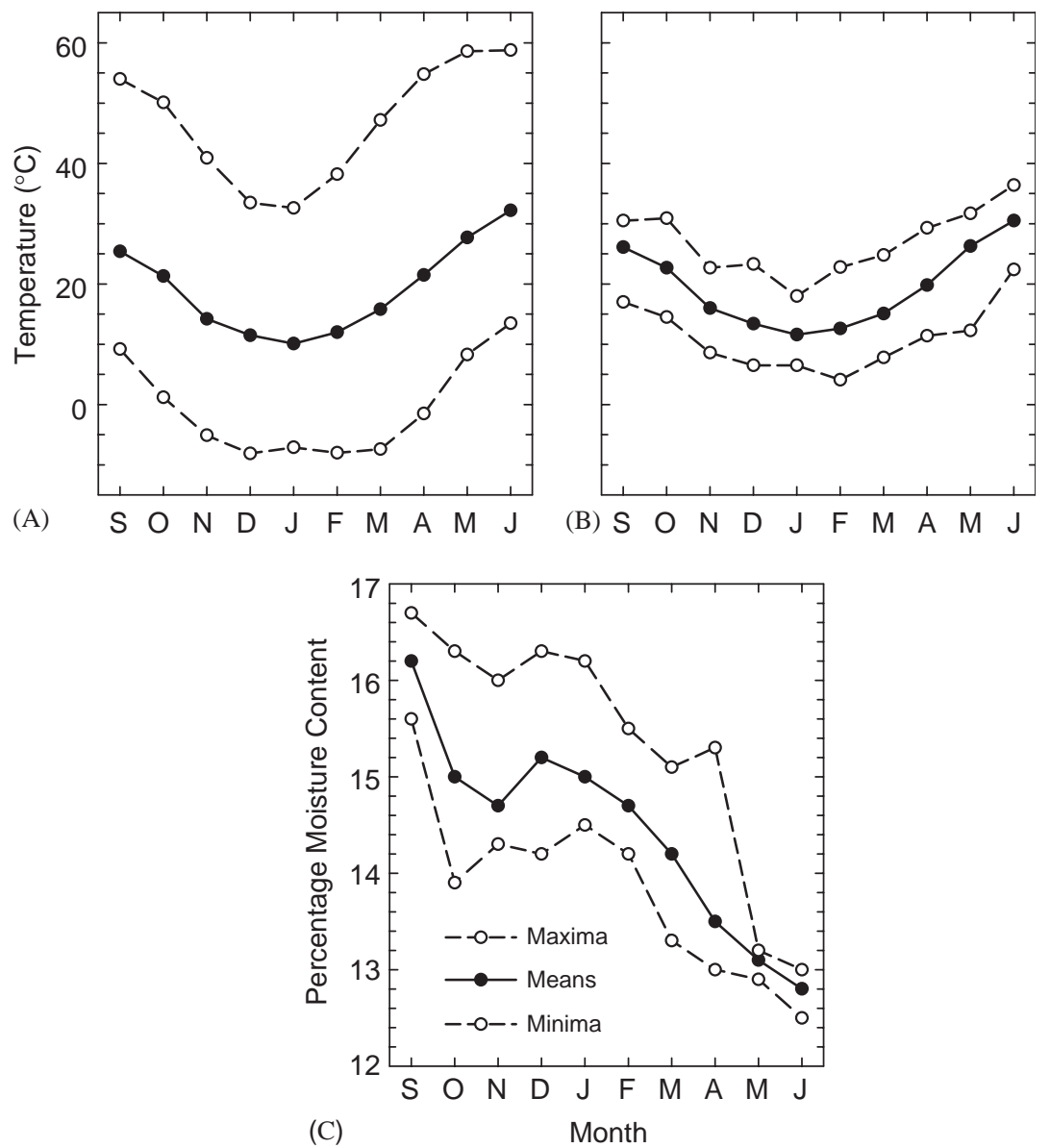

Fig. 1. Seasonal variation of headspace temperature (A), grain temperature (B), and grain moisture content (C) in maize storages on South Carolina farms. Monthly mean, minimum, and maximum grain temperatures were calculated from hourly bin means (average for six thermistor locations $18 \mathrm{~cm}$ below the grain surface). Monthly mean, minimum, and maximum moisture contents were calculated from weekly means, minima, and maxima based on six grain samples.

nighttime minima fell below $5{ }^{\circ} \mathrm{C}$. The nearly parallel isotherms of mean maximum and minimum grain temperature (Fig. 3C, D) reflect a gradual cooling and warming with little diurnal variation, although the slight curvature of the isotherms indicates at least some warming and cooling during the course of a day. Contrary to expectation, the direction of curvature indicates cooler temperatures at noon than at midnight; this difference was slight but consistent, ranging from 0.3 to $1.4^{\circ} \mathrm{C}$ for the mean maximum and from 0.5 to $0.8^{\circ} \mathrm{C}$ for the mean minimum. This anomaly in diurnal variation reflects the lag of grain temperature behind that of the ambient air.

The spatial distribution of grain temperature varied with season (Fig. 4), and with the exception of May and June, temperature was consistently higher on the south side of the bin than on the north (Fig. 4A, C) and higher on the west side than on the east (Fig. 4B, D). The average difference $\left( \pm\right.$ SE) between north and south was $3.4 \pm 0.5$ and $2.9 \pm 0.5^{\circ} \mathrm{C}$ for mean daily maximum and minimum, respectively. The average difference between east and west was less: 

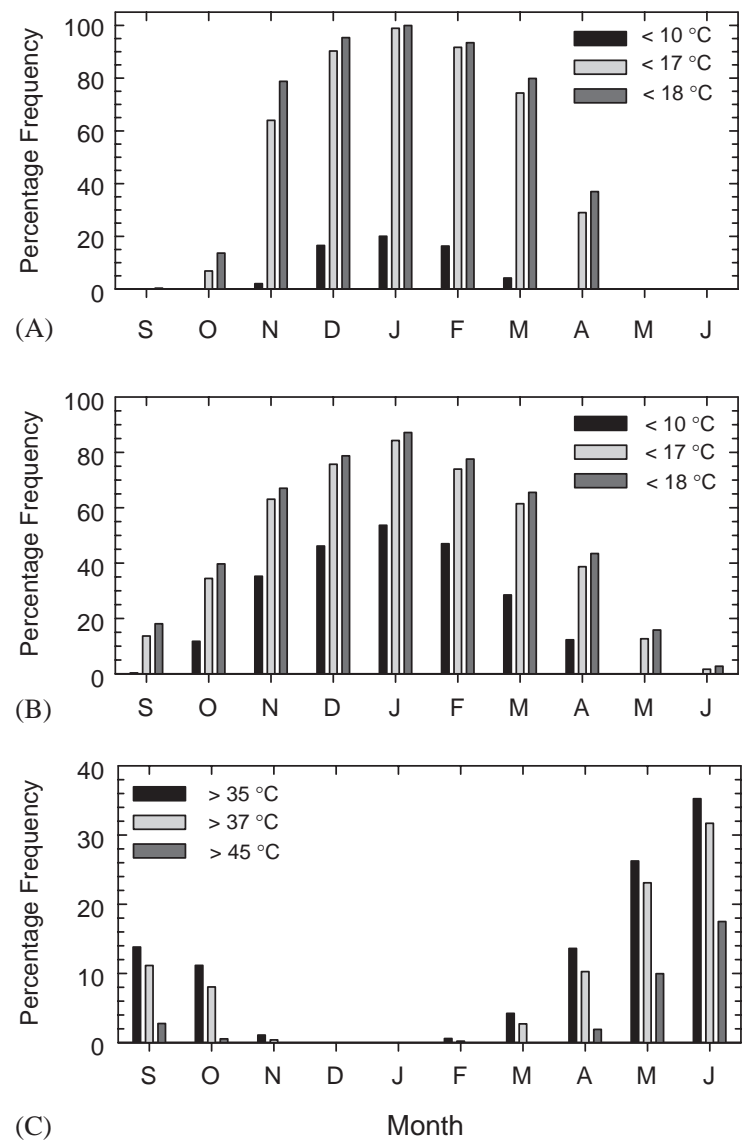

Fig. 2. Frequency of adversely high and low hourly headspace and grain temperatures in maize storages on South Carolina Farms. The temperatures are critical points for development, reproduction, survival and population growth of P. interpunctella and C. cautella. (A) Low hourly grain temperatures, (B) low hourly headspace temperatures, (C) high hourly headspace temperatures.

$1.6 \pm 0.2$ and $1.4 \pm 0.1^{\circ} \mathrm{C}$. During May and June, grain temperature was highest at the center of the bin (Fig. 4C, D).

Grain moisture content varied considerably from point to point in the bin, and bin averages fluctuated from week to week, but overall, moisture content declined over the course of a storage season (Fig. 1C). The maxima observed in the weekly samples (maximum for the nine subsamples) ranged from $15.9 \%$ to $27.5 \%$ (due in part to the occurrence of hot spots), and the minimum ranged from $11.0 \%$ to $12.2 \%$ (Table 2). Storage season means varied by as much as $2.3 \%$ from farm to farm and year to year.

\subsection{Moth populations and their natural enemies}

Population densities of both $P$. interpunctella and $C$. cautella, as indicated by the availability of mature larvae for pupation, fluctuated with an irregular period ranging from 2 to 6 weeks (Fig. 5). 

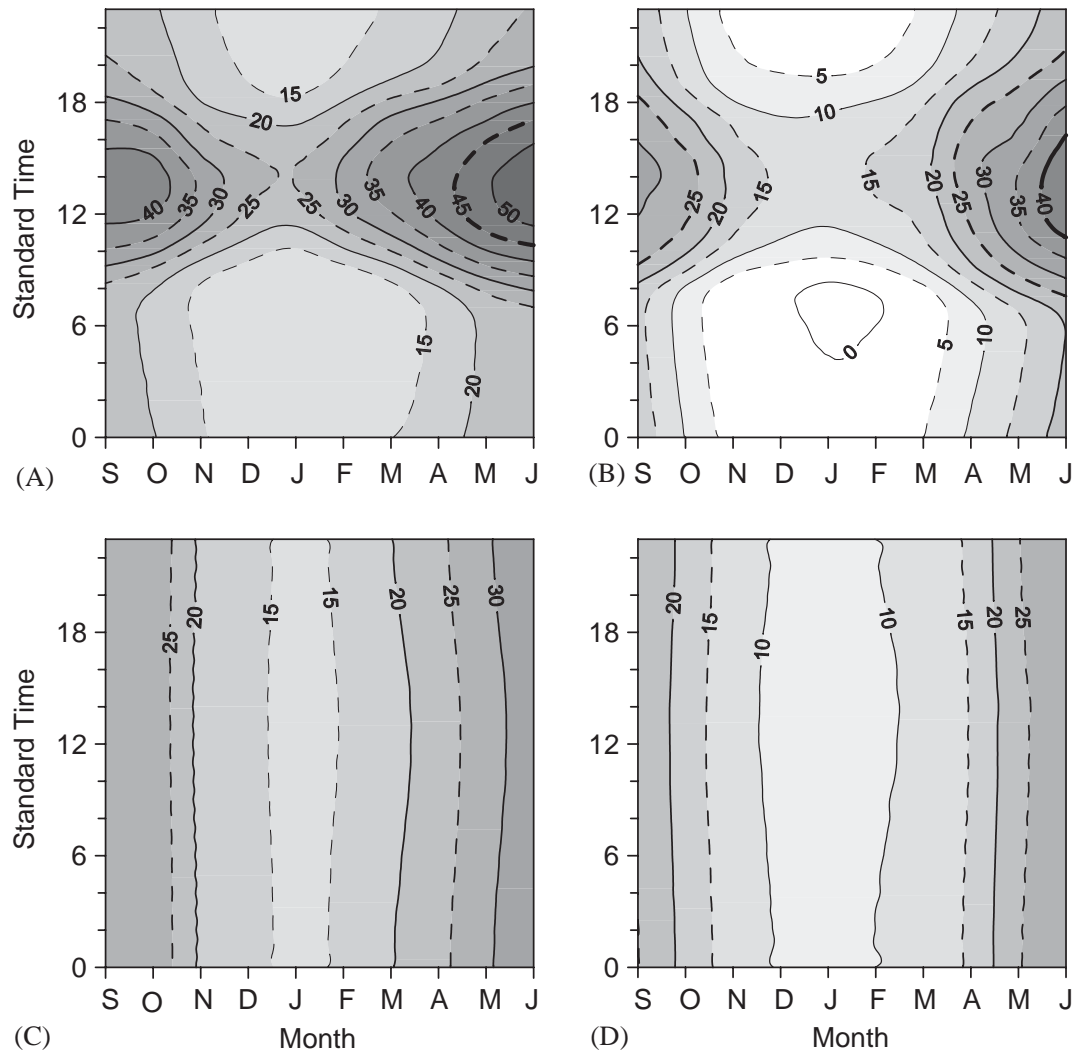

Fig. 3. Diurnal and seasonal variation of headspace and grain temperatures recorded in maize storages on South Carolina farms - isotherms represent mean hourly maxima and minima for each month. (A) Headspace mean maximum, (B) headspace mean minimum, (C) grain mean maximum, (D) grain mean minimum.

Plodia was generally the more abundant, but this was reversed in two instances-Bamberg in the fall of 1990 (Fig. 5A) and Barnwell during most of 1991-1992 (Fig. 5E). In addition to short-term fluctuation in numbers, there was some indication of a consistent seasonal trend in each species, which became quite clear when the counts for each farm and year were normalized, then pooled and averaged by week. Plots of the normalized weekly averages (Fig. 6) illustrate mean seasonal trends, independent of overall population level, for the 3 years of the study, and may be representative of most years on South Carolina farms. However, a longer period of study involving additional locations would be required to establish this conclusively. Populations of both species increased during the fall, slowly at first and then rapidly, reaching their highest levels during late fall and early winter (November-December). The populations began to decline during the winter, somewhat earlier in Plodia (Fig. 6A) than in Cadra (Fig. 6B), and continued to decline during the spring. By summer, both species had reached very low, barely detectable levels. There were a few exceptions to this pattern (Fig. 5), the most notable of which occurred during 1990-1991. During that year, the highest levels of Cadra at Bamberg (Fig. 5A) and Plodia at Barnwell (Fig. 5D) were recorded during the first week of trapping (October 17-24), and 

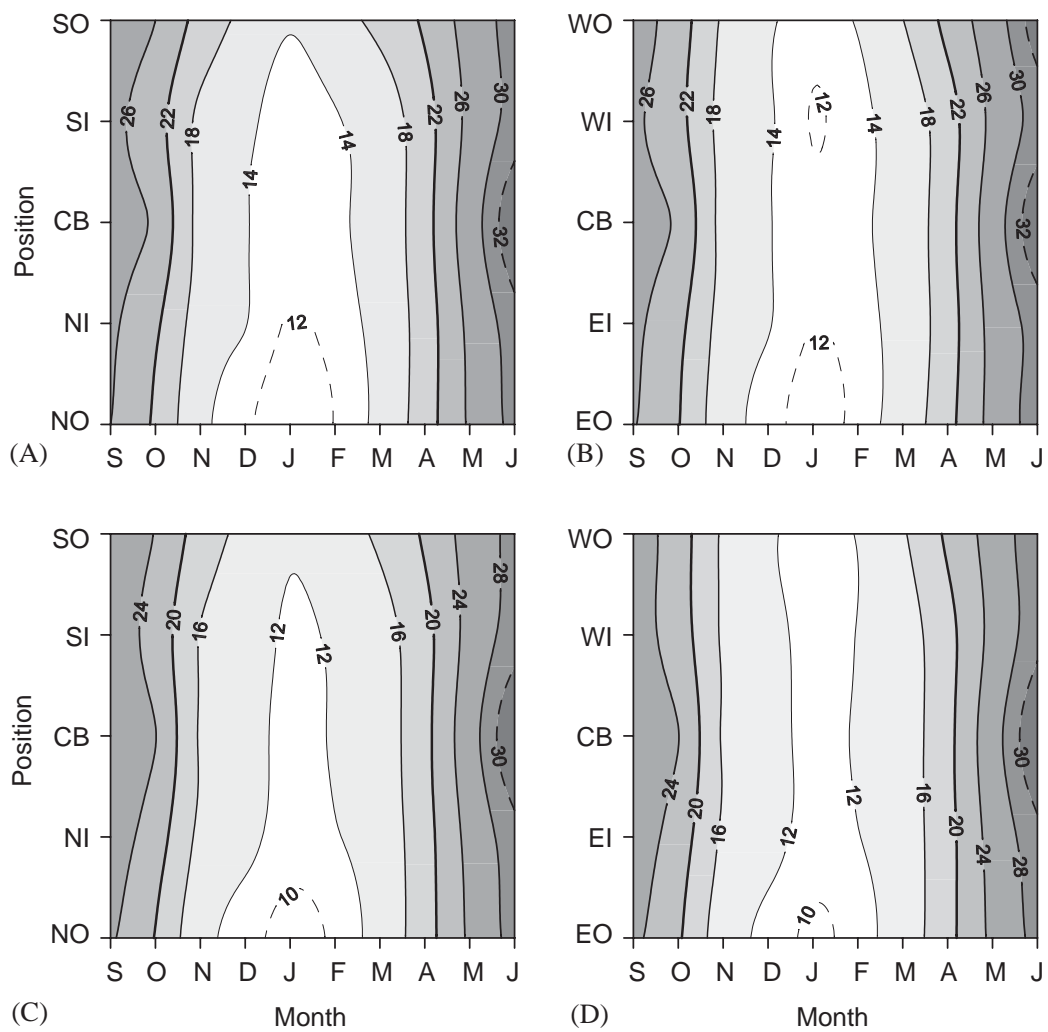

Fig. 4. Spatial and seasonal variation of grain temperature in maize storages on South Carolina farms. Isotherms represent mean daily maxima and mean daily minima by month along north-south and east-west bin diameters. Means are based on combined observations of two bins for three storage seasons. Positions are designated as CB (center of the bin) or as a compass direction ( N, E, S, W ) plus I (inner, nearer the center) or O (outer, nearer the bin wall). (A, B) Mean daily maximum, $(\mathrm{C}, \mathrm{D})$ mean daily minimum.

Table 2

Descriptive statistics, by location and storage period, for grain moisture content in maize storages on South Carolina farms

\begin{tabular}{lcccr}
\hline Date & $\mathrm{N}^{\mathrm{a}}$ & Mean \pm SD & Min & Max \\
\hline Bamberg County & & & & \\
24 Oct 1990-26 Jun 1991 & 36 & $13.5 \pm 0.9$ & 11.4 & 17.2 \\
11 Sep 1991-13 May 1992 & 36 & $14.5 \pm 0.7$ & 12.2 & 16.7 \\
18 Sep 1992-17 Jun 1993 & 40 & $15.8 \pm 1.2$ & & 18.0 \\
Barnwell County & & & 11.6 & \\
24 Oct 1990-29 May 1991 & 32 & $14.1 \pm 1.1$ & 11.8 & 15.5 \\
18 Sep 1991-22 Apr 1992 & 31 & $13.6 \pm 0.5$ & 12.1 & 17.5 \\
10 Nov 92-17 Jun 93 & 32 & $14.6 \pm 1.1$ &
\end{tabular}

Mean and SD for the storage period were calculated from weekly bin means (average moisture content of the nine grain samples collected each week). The minima and maxima are the highest and lowest values recorded for any individual sample during the storage period.

${ }^{a}$ Number of weekly means used to calculate the mean for the storage season. 

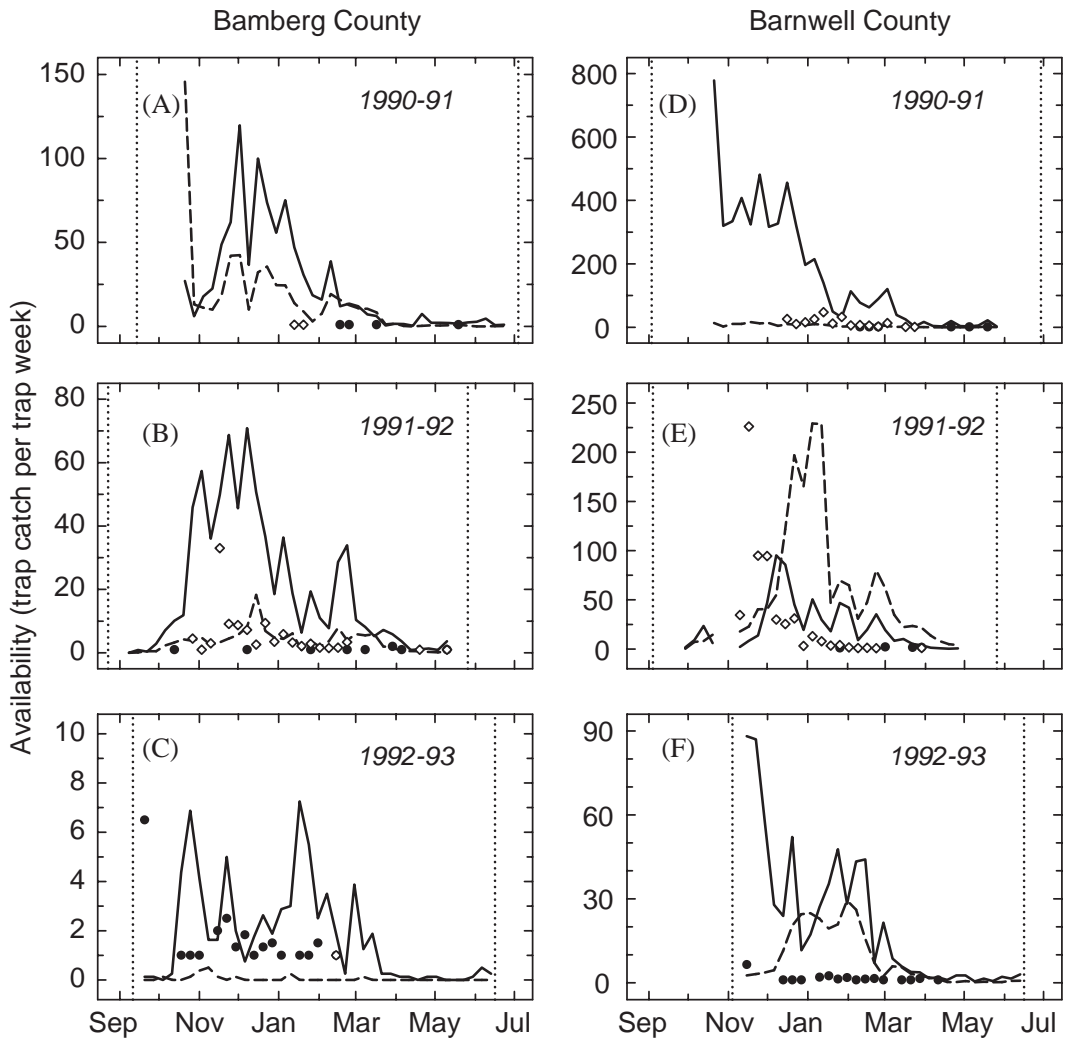

Fig. 5. Variation in abundance of $P$. interpunctella (solid line), C. cautella (dashed line), H. hebetor (solid circle), and $X$. flavipes (open diamond) in shelled maize stored on two South Carolina farms, as indicated by availability of mature larvae (moths) or adults (natural enemies). Trap weeks $=$ (number of traps) $\times$ (number of weeks). Dotted vertical lines indicate dates that bins were filled and emptied.

population levels may have been even higher, earlier in the fall, because trapping did not begin until 5-6 weeks after the bins were loaded. By the same token, population levels may have been quite low during the first 2 or 3 weeks of storage. Although there were exceptions to the timing of maximum abundance, both species invariably declined to very low levels during spring and summer.

The nearly constant pattern of seasonal abundance from farm to farm and year to year suggests regulation by a seasonal factor such as temperature. The occurrence of peak abundance during November and December, followed by the onset of population decline in late December and January suggests, adversely low temperature as a major factor initiating the decline (Fig. 6). Cox and Bell (1991) cited 18 and $17^{\circ} \mathrm{C}$ as the minimum temperatures for population increase of $P$. interpunctella and $C$. cautella, respectively. Exposure of adult $P$. interpunctella for relatively short periods ( $<30$ days) to $10{ }^{\circ} \mathrm{C}$ greatly reduces their fecundity and the viability of the eggs they produce; eggs held at $10^{\circ} \mathrm{C}$ suffer heavy mortality ( $>95 \%$ ) within 2 weeks (Johnson et al., 1997). Mating of $C$. cautella is infrequent at temperatures $\leqslant 13^{\circ} \mathrm{C}$ and few fertile eggs are laid; halfgrown to mature larvae held for 5 days at $0{ }^{\circ} \mathrm{C}, 32$ days at $5^{\circ} \mathrm{C}$, or 83 days at $10^{\circ} \mathrm{C}$ fail to complete 

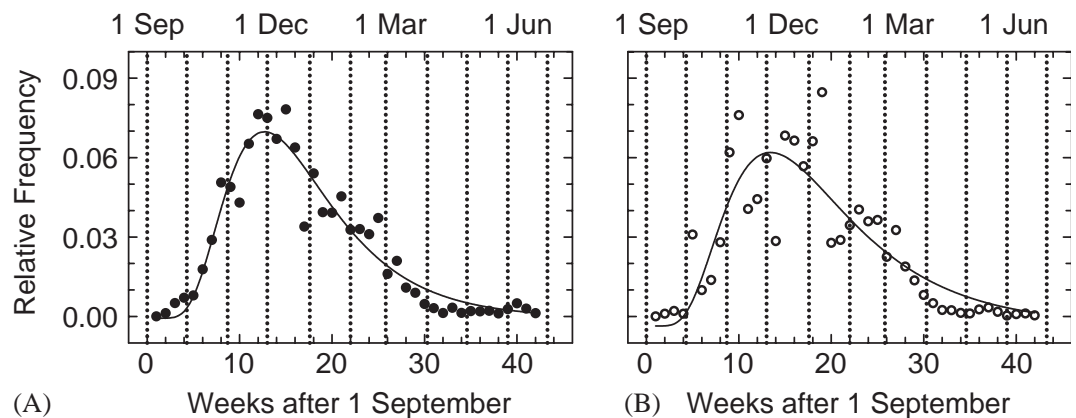

(B) Weeks after 1 September

Fig. 6. Seasonal trends in populations of P. interpunctella (A) and C. cautella (B) infesting maize stored on South Carolina farms, as indicated by numbers of mature larvae captured in coils of corrugated paper. The relative frequencies are for both farms and all storage seasons combined. Vertical dotted lines define the months: September-June.

Seasonal trends are approximated by the log normal equation: $y=a \exp \left\{\left[-\ln 2 / \ln d^{2}\right] \ln \left[\left((x-b)\left(d^{2}-1\right) / c d\right)+1\right]^{2}\right\}$.

\begin{tabular}{lllll}
\hline Parameters: & $a$ & $b$ & $c$ & $d$ \\
\hline P. interpunctella & 0.0705 & 12.7 & -0.000692 & 0.449 \\
C. cautella & 0.0656 & 13.4 & 0.003640 & 0.503 \\
Goodness of fit & $R^{2}$ & Adj. $R^{2}$ & $F(3,38)$ & $P>F$ \\
$P$. interpunctella & 0.927 & 0.920 & 162 & $<0.01$ \\
C. cautella & 0.760 & 0.734 & 46.3 & $<0.01$ \\
\hline
\end{tabular}

development (Burges, 1956). Newly hatched larvae of $C$. cautella die within 35 days at $10{ }^{\circ}$; those of $P$. interpunctella survive but die within 21 days at $8{ }^{\circ} \mathrm{C}$ (Stratil and Reichmuth, 1984).

The continuation of decline through spring to near extinction in early summer suggests the operation of other factors, including adversely high temperatures. Cox and Bell (1991) cited 35 and $37^{\circ} \mathrm{C}$ as the maximum temperatures for development of $P$. interpunctella and C. cautella, respectively. Burges and Haskins (1965) reported the upper limit for development of $C$. cautella to be about $36^{\circ} \mathrm{C}$. Pupae of $P$. interpunctella and $C$. cautella are killed by a 2-h exposure to $50{ }^{\circ} \mathrm{C}$, and the median lethal exposure $\left(\mathrm{LT}_{50}\right)$ to $45^{\circ} \mathrm{C}$ is $<3 \mathrm{~h}$ for pupae of $C$. cautella and $<0.5 \mathrm{~h}$ for those of $P$. interpunctella (Arbogast, 1981). Nonlethal exposures to high temperature can adversely affect growth and reproduction. Arbogast (1981) found that nonlethal exposure of male or female pupae of $P$. interpunctella and $C$. cautella to a high temperature $\left(40\right.$ or $\left.45^{\circ} \mathrm{C}\right)$ produced a high percentage of adults with malformed wings, caused some failure to mate, and reduced fecundity, but did not reduce the hatchability of the eggs laid. Tuli et al. (1966) recorded a considerable reduction in fecundity of $C$. cautella reared at $35^{\circ} \mathrm{C}$ compared to those reared at 15 to $30^{\circ} \mathrm{C}$, and Abdel-Rahman (1971) noted that fewer $P$. interpunctella completed development at 35 than at $30{ }^{\circ} \mathrm{C}$. Lum (1977) found that pupae of $P$. interpunctella exposed to $36^{\circ} \mathrm{C}$ for 6 days (the entire pupal period) all died; some $C$. cautella pupae survived, although the adults were malformed and did not reproduce. He also found that exposure to 34 or $35^{\circ} \mathrm{C}$ for 6 days reduced the fecundity of both species. Fertility remained high (60-80\%) after exposure to $34{ }^{\circ} \mathrm{C}$ but was reduced to $5 \%$ after exposure to $35^{\circ} \mathrm{C}$. 
The known biological limitations of $P$. interpunctella and $C$. cautella described above, in conjunction with our observations of temperature (Figs. 1A, B, 2, and 3) and larval abundance (Fig. 6), support the hypothesis that seasonal variation in abundance was determined in part by the seasonal distribution of adverse temperature extremes. In examining this hypothesis, it is important to note that the relationship between temperature and availability is determined by the impact of temperature on mating, fecundity, and mortality during development. Therefore, manifestation of a temperature effect, such as the number of larvae in a coil, lags behind the temperature effect by a period that varies with the rate of development. As a point of reference, development of $P$. interpunctella on cracked corn, from oviposition to adult emergence, requires an average of about 31-80 days at temperatures ranging from 20 to $35^{\circ} \mathrm{C}$, with the most rapid development at $30^{\circ} \mathrm{C}$ (Arbogast, unpublished data). Examination of the hypothesis, is further complicated by the temperature gradient that must necessarily exist between the headspace and grain at various depths, and which provides a range of temperatures for development.

The number of larvae collected in the coils reached a peak during November and December, and then began to decline in late December to early January (Fig. 6). The onset of population decline followed a sharp increase in frequency of low temperatures during November, especially of low grain temperature (Fig. 2A, B). The grain and headspace began to warm after January, but from November-March, more than half the hourly temperatures were $<17^{\circ} \mathrm{C}$, and in the headspace more than a quarter were $<10^{\circ} \mathrm{C}$ (Fig. 2A, B). Yet, the suppressive effect of low temperature may have been moderated somewhat by higher midday temperatures in the headspace (Fig. 3A, B), and also in a shallow surface layer of grain warmed by the air of the headspace. The moth populations continued to decline as the grain storages warmed in the spring and by May they were on the verge of extinction. Adversely high temperature may have contributed to final population collapse. Although grain temperature did not exceed $35^{\circ} \mathrm{C}$, except for short periods during June (Fig. 1B), headspace temperature frequently exceeded the upper limit for development (Fig. 2C) and reached damaging levels during the day (Figs. 2C and 3A, B). Although the evidence for temperature mediated variation in abundance is not conclusive, the evidence is sufficiently strong to merit further investigation.

Grain moisture content declined during storage but never dropped low enough to be a significant factor in decline of the moth populations. The lowest value recorded during the study was $11.0 \%$. Cox and Bell (1991) cited 20\% r.h. as the minimum humidity for population increase of both $P$. interpunctella and $C$. cautella. The levels of relative humidity in equilibrium with a moisture content of $11.0 \%$ - calculated by means of the regression equation presented by Throne (1994) - ranged from $41.0 \%$ r.h. at $15^{\circ} \mathrm{C}$ to $55.3 \%$ at $40{ }^{\circ} \mathrm{C}$, well above the lower limit for population increase.

Likewise, malathion residues were probably of little consequence, because high levels of resistance are known to occur in both $P$. interpunctella and C. cautella (Zettler et al., 1973; Zettler, 1982). Furthermore, data reported by Arbogast et al. (2000) showed that malathion residues on farm-stored corn in South Carolina decline exponentially throughout the storage season. Thus, maximum growth of the moth populations occurred when malathion levels were at their highest.

In addition to moth larvae and pupae, adults and immature stages of $X$. flavipes and $H$. hebetor frequently occurred in the coils (Fig. 5). Larvae of $H$. hebetor were often found feeding on moth larvae, many of which showed the blackened areas characteristic of wounds inflicted by nymphs and adults of $X$. flavipes or adult $H$. hebetor. Other larvae exhibited the chalky appearance 
symptomatic of granulosis virus infection. Specimens of the predatory mite Blattisocius keegani Fox (Acarina: Ascidae) were collected on March 5, 1992 from adults of $P$. interpunctella and $C$. cautella on both farms and from coils on the Barnwell farm. A specimen of Cheyletus malaccensis Oudemans (Acarina: Cheyletidae) was collected on the same day from a coil in the Bamberg bin. Although these collections established the presence of predatory mites, no samples were taken to estimate their population levels.

Current population theory suggests that the short-term fluctuations in availability of Plodia and Cadra larvae (Fig. 5) could be explained in part by the density-dependent action of natural enemies and disease. Theoretical studies and laboratory experiments conducted under constant physical conditions with carefully regulated food supplies have shown that cycles in populations of various stored-product Pyralidae are regulated by competition, cannibalism, predation, and disease (White and Huffaker, 1969a, b; Sait et al., 1994; Begon et al., 1996, Briggs et al., 2000; Rohani et al., 2003). The period of these cycles may approximate to a single generation or multiple generations, depending upon which agents are present, and the amplitude of fluctuation may be sufficient to make extinction likely. These findings suggest that natural enemies and disease, in addition to adverse temperature, may have contributed to the population collapse observed in the present study.

There is ample evidence that predators and parasitoids can play a significant role in the decline of moth populations in storages. Graham (1970), for example, described the buildup and decline of $C$. cautella infesting bagged maize in Kenya, and concluded that predation by the mite Blattisocius tarsalis Berlese (Acarina: Ascidae) was the major cause of decline. Benson (1974) examined the interaction of $C$. cautella with the parasitoid wasp H. hebetor by regular sampling of caged populations in the laboratory and concluded that mortality of third and fourth instars inflicted by female parasitoids, which paralyze and feed upon these stages, is a major cause of mortality. Keever et al. (1985) described the apparent suppression of $P$. interpunctella and $C$. cautella by $H$. hebetor on stored groundnuts in Georgia, and noted that the population trends of the moths and parasitoid were similar to those observed for the first several generations of interacting $H$. hebetor and C. cautella populations in the laboratory study by Benson (1974). LeCato et al. (1977) reported that $X$. flavipes curtailed population growth of $C$. cautella infesting small quantities of rolled oats that were scattered on the floor of a warehouse room to simulate grain debris.

The presence of larvae exhibiting symptoms of granulosis infection raises the possibility that viral infection may have been a factor in final population decline. We did not collect data to determine the incidence of the virus at various points in the storage period, but viruses sometimes increase over time in undisturbed habitats as a result of cumulative contamination, and eventually cause host population collapse. This phenomenon is known to occur in old pastures (Fleming et al., 1986), and Sait et al. (1994) suggested that a similar situation probably existed in laboratory cages of infected $P$. interpunctella. The virus could be expected to accumulate rapidly in the limited space of a grain bin, where it is protected from degradation by UV light. Another mechanism of viral-induced decline that could have occurred in the grain bins is a change from covert viral infections transmitted vertically (from parent to offspring) to lethal horizontally transmitted infections (Burden et al., 2002, 2003). There is some evidence (though not conclusive) that this change occurs when the hosts become stressed by crowding, adverse temperature, etc. 


\section{Conclusions}

The most significant findings of the present study were (1) a seasonal pattern of abundance in both moth species that persisted from farm to farm and year to year, and (2) the coincidence of the highest population levels with the lowest temperatures. With few exceptions, the populations increased in the fall, reached their highest levels in winter, and then declined to low levels by early spring. The persistence of this pattern suggests a seasonal regulatory mechanism, with onset of low temperature as the primary initiator of population decline and adversely high temperature as a contributor to its protraction through spring into early summer. This view is supported by our observations of temperature and moth abundance, in conjunction with published information on the biological limitations of the two species. However, other factors, such predators, parasitoids, and viral infection, may have contributed to final population collapse.

Superimposed upon the seasonal trends were short-term, non-seasonal cycles of abundance with variable periods. Current population theory, together with the presence of B. keegani, X. flavipes, $H$. hebetor, and granulosis virus suggest that predation, parasitism, disease, and competition may have produced these cycles. However, this hypothesis remains to be tested by studies that seek to identify and quantify mortality factors that impact each stage of an insect population breeding in storage situations. Although the mechanisms of population regulation predicted by theoretical studies and revealed by laboratory experimentation may not be readily apparent in storages, they must still act in such situations, in spite of differences in scale and vastly more complex webs of interaction. As the mechanisms operating in storage ecosystems are identified and their importance assessed, they can be incorporated into models for simulating the dynamics of the system. A population model is already available for $C$. cautella (Throne et al., 1998), and we are collaborating with USDA scientists at the Grain Marketing and Production Center, Manhattan, KS, who are developing a model for P. interpunctella, based in part on demographic data for moths collected in bins on the two South Carolina farms and reared in the laboratory on maize. Both models could eventually be refined by incorporating additional population regulating mechanisms, and the models could in turn be used to study the operation of regulating mechanisms under a variety of storage conditions. As pointed out by Throne (1995), modeling begins with the simplest model, but all biotic and abiotic factors that have a major influence on the storage ecosystem, and the interactions among them, must eventually be included to produce a successful model and to optimize management of the system.

\section{Acknowledgments}

We are indebted to R. Rentz and J.J. Bates for their cooperation and support of our research on their farms. We thank R.V. Byrd and B.R. Flaherty for their help with the field work and M. Carthon, who assisted in the laboratory by counting and identifying insects and tabulating data. Specimens of predaceous mites were identified by R.L. Smiley and specimens of $X$. flavipes were identified by T.J. Henry, both at the Systematic Entomology Laboratory, ARS, USDA. We are indebted to S.M. Sait, School of Biology, University of Leeds, who provided information on virus-host interactions and helpful suggestions. Finally, we thank F.H. Arthur and J.F. Campbell for their critical review of an earlier version of the manuscript and for their helpful comments. 


\section{References}

Abdel-Rahman, H.A., 1971. Some factors influencing the abundance of the Indian meal moth, Plodia interpunctella $\mathrm{Hb}$., on stored shelled corn. Bulletin. Société entomologique d'Égypte 55, 321-330.

Arbogast, R.T., 1981. Mortality and reproduction of Ephestia cautella and Plodia interpunctella exposed as pupae to high temperatures. Environmental Entomology 10, 708-711.

Arbogast, R.T., Throne, J.E., 1997. Insect infestation of farm-stored maize in South Carolina: towards characterization of a habitat. Journal of Stored Products Research 33, 187-198.

Arbogast, R.T., Kendra, P.E., Weaver, D.K., Subramanyam, Bh., 2000. Phenology and spatial pattern of Typhaea stercorea (Coleoptera: Mycetophagidae) infesting stored grain: estimation by pitfall trapping. Journal of Economic Entomology 93, 240-251.

Begon, M., Sait, S.M., Thompson, D.J., 1996. Predator-prey cycles with period shifts between two- and three-species systems. Nature 381, 311-315.

Benson, J.F., 1973. The biology of Lepidoptera infesting stored products, with special reference to population dynamics. Biological Reviews 48, 1-26.

Benson, J.F., 1974. Population dynamics of Bracon hebetor Say (Hymenoptera: Braconidae) and Ephestia cautella (Walker) (Lepidoptera: Phycitidae) in a laboratory ecosystem. Journal of Animal Ecology 43, 71-86.

Briggs, C.J., Sait, S.M., Begon, M., Thompson, D.J., Godfray, H.C.J., 2000. What causes generation cycles in populations of stored-product moths? Journal of Animal Ecology 69, 352-366.

Burden, J.P., Griffiths, C.M., Cory, J.S., Smith, P., Sait, S.M., 2002. Vertical transmission of sublethal granulosis infection in the Indian meal moth, Plodia interpunctella. Molecular Ecology 11, 547-555.

Burden, J.P., Nixon, C.P., Hodgkinson, A.E., Possee, R.D., Sait, S.M., King, L.A., Hails, R.S., 2003. Covert infection as a mechanism for long term persistence of baculoviruses. Ecology Letters 6, 524-531.

Burges, H.D., 1956. Some effects of the British climate and constant temperatures on the life-cycle of Ephestia cautella (Walker). Bulletin of Entomological Research 46, 813-835.

Burges, H.D., Haskins, K.P.F., 1965. Life cycle of the tropical warehouse moth, Cadra cautella (Wlk.), at controlled temperatures and humidities. Bulletin of Entomological Research 55, 775-789.

Cox, P.D., Bell, C.H., 1991. Biology and ecology of moth pests of stored foods. In: Gorham, J.R. (Ed.), Ecology and Management of Food-industry Pests. Association of Official Analytical Chemists, Arlington, VA, pp. 181-193.

Fleming, S.B., Kalmokov, J., Archibald, R.D., Stewart, K.M., 1986. Density-dependent virus mortality in populations of Wiseana (Lepidoptera, Hepialidae). Journal of Invertebrate Pathology 48, 193-198.

Graham, W.M., 1970. Warehouse ecology studies of bagged maize in Kenya-II. Ecological observations of an infestation of Ephestia (Cadra) cautella (Walker) (Lepidoptera, Phycitidae). Journal of Stored Products Research 6, $157-167$.

Hagstrum, D.W., Sharp, J.E., 1975. Population studies on Cadra cautella in a citrus pulp warehouse with particular reference to diapause. Journal of Economic Entomology 68, 11-14.

Horton, P.M., 1982. Stored product insects collected from on-farm storage in South Carolina. Journal of the Georgia Entomological Society 17, 485-491.

Johnson, J.A., Valero, K.A., Hannel, M.M., 1997. Effect of low temperature storage on survival and reproduction of Indianmeal moth (Lepidoptera: Pyralidae). Crop Protection 16, 519-523.

Keever, D.W., Arbogast, R.T., Mullen, M.A., 1985. Population trends and distributions of Bracon hebetor Say (Hymenoptera Braconidae) and lepidopterous pests in commercially stored peanuts. Environmental Entomology 14, $722-725$.

LeCato, G.L., Collins, J.M., Arbogast, R.T., 1977. Reduction of residual populations of stored-product insects by Xylocoris flavipes (Hemiptera Anthocoridae). Journal of the Kansas Entomological Society 50, 84-88.

Lum, P.T.M., 1977. High temperature inhibition of development of eupyrene sperm and of reproduction in Plodia interpunctella and Ephestia cautella. Journal of the Georgia Entomological Society 12, 199-203.

Richards, O.W., Thomson, W.S., 1932. A contribution to the study of the genera Ephestia Gn. (including Strymax Dyar), and Plodia Gn. (Lep. Phycitidae), with notes on parasites of the larvae. Transactions of the Royal Entomological Society of London 80, 169-250. 
Richards, O.W., Waloff, N., 1946. The study of a population of Ephestia elutella Hübner (Lep., Phycitidae) living on bulk grain. Transactions of the Royal Entomological Society of London 97, 253-298.

Rohani, P., Wearing, H.J., Cameron, T., Sait, S.M., 2003. Natural enemy specialization and the period of population cycles. Ecology Letters 6, 381-384.

Sait, S.M., Begon, M., Thompson, D.J., 1994. Long-term population dynamics of the Indian meal moth Plodia interpunctella and its granulosis virus. Journal of Animal Ecology 63, 861-870.

Stratil, H.H., Reichmuth, C., 1984. Development of young larvae of the stored product moths Ephestia cautella Walker, Ephestia elutella Hübner and Plodia interpunctella Hübner (Lepidoptera, Pyraloidea) at low temperature. Anzeiger für Schädlingskunde und Pflanzenschutz 57, 30-33.

Southwood, T.R.E., 1978. Ecological Methods with Particular Reference to the Study of Insect Populations. Chapman \& Hall, London.

Throne, J.E., 1994. Life history of immature maize weevils (Coleoptera Curculionidae) on corn stored at constant temperatures and relative humidities in the laboratory. Environmental Entomology 23, 1459-1471.

Throne, J.E., 1995. Computer modeling of the population dynamics of stored-product pests. In: Jayas, D.S., White, N.D.G., Muir, W.E. (Eds.), Stored Grain Ecosystems. Marcel Dekker, New York, pp. 169-195.

Throne, J.E., Hagstrum, D.W., Nawrot, J., 1998. Computer model for simulating almond moth (Lepidoptera Pyralidae) population dynamics. Environmental Entomology 27, 344-354.

Tuli, S., Mookerjee, P.B., Sharma, G.C., 1966. Effect of temperature and humidity on the fecundity and development of Cadra cautella Wlk. in wheat. Indian Journal of Entomology 28, 305-317.

White, E.G., Huffaker, C.B., 1969a. Regulatory processes and population cyclicity in laboratory populations of Anagasta kühniella (Zeller) (Lepidoptera Phycitidae). I. Competition for food and predation. Researches on Population Ecology 11, 57-83.

White, E.G., Huffaker, C.B., 1969b. Regulatory processes and population cyclicity in laboratory populations of Anagasta kühniella (Zeller) (Lepidoptera Phycitidae). II. Parasitism, predation, competition and protective cover. Researches on Population Ecology 11, 150-185.

Zettler, J.L., McDonald, L.L., Redlinger, L.M., Jones, R.D., 1973. Plodia interpunctella and Cadra cautella resistance in strains to malathion and synergized pyrethrins. Journal of Economic Entomology 66, 1049-1050.

Zettler, J.L., 1982. Insecticide resistance in selected stored-product insects infesting peanuts in the southeastern United States. Journal of Economic Entomology 75, 359-362. 